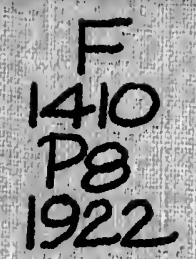

\title{
PRIESTLEY
}

\section{SPANISH COLONIAL MUNICIPALITIES}

\section{BAHCEOT}


The Bancroft Library University of California - Berkeley 
Digitized by the Internet Archive in 2007 with funding from Microsoft Corporation 


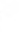




\title{
Spanish Colonial Municipalities
}

\author{
By Herbert Ingram Priestley, Ph. D.
}

Librarian of the Bancroft Library and Associate Professor of Mexican History in the University of California 


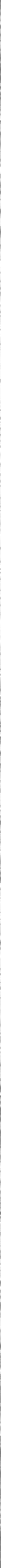


Reprint from The Louisiana Hislorical Quarterly

April, 1922.

\section{SPANISH COLONIAL MUNICIPALITIES}

By Herbert Ingram Priestley, Ph. D.

Librarian of the Bancroft Library and Associate Professor of Mexican History in the University of California.

This article was originally pinted in the California Law Review for September, 1919, and translated into Spanish by Genaro Estrada and published as Munieipalidades coloniales españolas, Mexico, 1921. It is republished by the Louisiana Historical Quarterly with the consent of Mr. Priestley and we are quite sure that Louisiana students of Spanish institutions in Louisiana will be quick to appreciate this ver $y$ valuable contribution to a subject that un to this time has been very inadequately treated here or elsewhere.

With the light thrown on the subject by Mr. Priestley's essay, many of the misunderstood features of the Spanish Cabildo in Louisiana will be restored to their true position in our history. HENRY P. DART.

\section{Spanish Colonial Municipalities.}

The municipal organization of Castile, transferred to America soon after the advent of Columbus, began to function with no lack of vitality. The first conquerors brought to the New World a traditional love of liberty and a spirit of strong local autonomy which promised fair for development in the conquered and colonized territory. But during the sixteenth century the Spanish peninsular municipio was reduced from its earlier importance and power, being subjected to centralized control by officers of the crown. These were the gobernadores, corregidores, and alcaldes mayores, who went out to hold the local areas in the name of the national authority. These centrally appointed officers substituted for the direct democracy guaranteed by the municipal fueros, (charters), and for the system of local legislation arising from the petitions of the towns through their procuradores, a direct central legislation. under royal cédulas, cartas, and instrucciones. Thus, through the conflict of the monarchs with 
the towns was eliminated the initiative of earlier, more independent days.'

The significant characteristic of these peninsular cabildos (town corporations) before the epoch of Charles $\mathrm{V}$ was the possession of rights similar to those which had been won by Englishmen in their struggle for political liberty under their kings. The Spanish townsmen had established under their fueros the equality of all the citizens before the law. The character of the vecino (townsman) was superior to all social distinctions. This equality was considered essential for wise government of the commune, and if any counts, knights, or other noblemen should come to settle in it they must become subject to the same restrictions, including death penalties for certain crimes, as the earlier settlers.

In the Spanish towns the principle of the inviolability of the domicile was well recognized. It was not the Englishman alone who could claim that his house was his castle. Violation of this right was punished by the severest penalty, even death. In the fueros of Cuenca and Sanabria the method of entering the domicile under the authority of search warrant is prescribed with the same precaution and respect for the rights of the inhabitants as are shown in the most modern legislation.

Furthermore, justice was dispensed to the citizen by his peers, chosen by him or by his counsel, save in matters wherein the royal jurisdiction intervened. No man might be deprived of life or property, nor be arrested by the merinos (king's justices) except in matters on which the local judges had already passed sentence. If the merinos passed such sentences, they were to be disobeyed.

Every man had a right to participate in public affairs. He shared in the election of magistrates. The authority of the town government was based on popular election; this constituted the legitimate sanction of the officer in the exercise of his duties under the local fueros. No confirmation of his powers from any authority outside of the municipality was necessary; not even the king had any intervention in the naming of the municipal officers."

'R. Altamira. Historia de España "/ de la civilisación española, II, 483: Carlos Navarro y Lamarca. Compendio de la historia general de América, II. 339.

2J. A. Garcia, La ciudad indiana, 161. 
With respect to the responsibility of the officers of the Castilian city, the ancient legislation provided more amply, perhaps, than does much of the modern. "Injuries caused to citizens were to be compensated for doubly if by an officer; infractions of the fueros or deception in controlling public interests were punished severely as breaches of trust by loss of position. Instead of forming a shield for iniquity, municipal office brought upon an offender punishment twice as severe as that imposed in like case upon the private citizen, the public trust being construed as aggravating the offense."

All this was absent in the Spanish-American municipality. The guarantees of the citizen were wanting. There was, too, the lack of forceful union between the towns, union which had in Spain given stability and respectability to the pretensions of the local entities. This had been secured through the Santa Herman$d a d$, which in the earlier times constituted the visible arm of the united power of Castilian towns. But in America this source of dignity and power was at first altogether lacking; when the Hermandad did appear, it was as the arm and token of the central authority, imposed from above for the protection of the roads against highwaymen. Serving as an attempt to guarantee safety in the interstices between the areas controlled by the municipalities, the Hermandad lent none of its majesty to the local government, and served rather to aggrandize the central control and prevent development of local autonomy.

As far as form went, however, the local units of the New World modeled their government upon that of the towns of Spain. Municipal organizations, provided for under Columbus, and extended throughout La Española in .1507, began to exist wherever a group of Spaniards was numerous enough to require social control. By the last quarter of the sixteenth century there were at least two hundred such organizations in the Spanish Indies, under the designation of ciudad, pueblo, or villa. In some places the name lugar (literally "place") was used to designate the pueblo, but the latter word was used in most cases to designate settlements other than mining camps (reales de minas) not large enough to be called ciudades. In the period last mentioned a number of the earliest towns had died with the shifting movements incidental to continental settlement when once the larger land

${ }^{3}$ García, Op. et loc. cit. 
masses had been found to excel the insular holdings in opportunity for enrichment.

Essentially, whatever the designation, all the municipalities enjoyed the same legal status. There were minor variations in the composition of the official governing body, the elaborateness of the organization corresponding to development in size. Blackmar, who shows the derivation of the Spanish towns from the Roman ones in Spain, points out clearly that, whatever might have been the variety of the organization of the peninsular towns, there was practical uniformity in style of organization in the colonial municipalities. Bernard Moses draws attention to the fact that the colonial cities might owe their origin to development from an Inciian mission or from a presidio, or that they might be founcled outright as cities by an individual conqueror or by a group of settlers voluntarily associated for the purpose. ${ }^{4}$ These variations in origin meant, however, no diversity in character among the municipal entities once they were organized. This uniformity was due to the existence of early general legislation and to the absence of those special frontier conditions which had in Spain made the successive reconquests from the Moors the basis for grants of widely divergent fueros and special privileges. ${ }^{5}$

In all of the municipalities the essential officers were the regidores (town councilmen). Their number was variable, ranging from four in the small villas to eight in the large ciudades and to twelve in the capitals, as for instance Mexico and Lima. Their importance was due to the fact that they had power of decision in matters of routine administration, and because from their number were annually chosen the alcaldes ordinarios (municipal judges, usually two in number) and the alferez (herald), whose function it was to bear the municipal banner on festal days. In occasional instances, the alférez was also a regidor. After the inception of the Hermandad in the New World, its alcaldes were chosen from among the alcaldes ordinarios; this was later than

"Frank IV. Thackmar. spanish Instiutions of the Southuest (Johns Hopkins sturlieg ju flistory nul lolitical sejne? Extra Volune $\mathrm{x}$. Baltimore. 1891), Chap. Virl, "spanish Colonial Municipatities"; Brord Mrses. "The Establishment of Munfeipal Govermment in San F* ancisco" (.lohns Topkins University Studies in Mis-

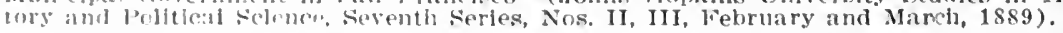

"I tegislation (overing foundation of early nunicinalities is found in ordenanzas sobre desenbrimicuto nurvo y poblución. in Colccción de dooumentos inedilos relativos "lesmbrimiruto, conquista "organización de las antiguas posesiones españolas de A merira y Oeernia, Tom. $8 \mathrm{pp}$. 4S4-527. This legislation was afterward largely incolporatul in the lieropilacion re ludias. The general law has been recanitulated by O. Ciarfield Jones under the title "Ioeal government in the Spantsh colonies as provider liy the fircopilarion dr leyes de los liemnos de las Indias", in The Southwestern IItstorical Qunrteriy, Vol. 19, pp. 65-90. 
the beginnings of municipal administration; in Lima, for instance, the alcaldes of the Hermandad did not appear until 1560." In New Spain the alcaldes of the mesta, or grazers' guild, appear among the list of annually elected municipal officers until well toward the end of the eighteenth century. ${ }^{7}$

The number of regidores varied from one period to another, as well as in classes of towns. In the Ordenanzas, cited above, it was provided that the governor of a new territory within which a city was to be erected should make declaration whether the new establishment was to be designated a ciudad, villa, or lugar (pueblo). The government of a metropolitan city was to contain one alcalde mayor or corregidor, he being characteristically the appointee of the central or provincial power. In his hands was to be placed the jurisdiction in solidum. 'The capitulares (town officials) designated in accordance with the colonizing grant, were to be the three oficiales reales (treasury officers), twelve regiclores, two jueces ejecutores, and a small number of accessory executive and clerical subordinates. Two of these were the jurados, one of whom was prescribed for each parish in the new settlement, perhaps the prototypes of the later alcaldes de barrio of the eighteenth century. The procurador general, known as time went on as the sindico (city attorney), was a man of recognized ability, social category, and political influence in the community. ${ }^{8}$

For the smaller settlements, known as villas, pueblos, or lugares, the Ordenanza of 1563 provided one alcalde ordinario, four regidores, one alguacil or bailiff, and some minor officers. Here the alcalde mayor or corregidor was wanting; this would indicate that municipal life was more free from the trammels of supervision in the smaller places, or that the alcalde mayor extended his control to the lesser from the larger settlements, as later came to be the rule.

In the closing years of the colonial epoch, the number of regidores was set at twelve for the larger cities; eight was the number considered proper for Guanajuato and San Luis Potosí in New Spain, while most of the smaller towns were to have six. In the City of Mexico there were fifteen. ${ }^{9}$

-Altamira, Historia de España, II, 313.

${ }^{7} \mathrm{~A}$. Cavo, Los Tres siglos de Mexico, passím.

${ }^{8}$ Lucas Alamán, Historia de Méjico. I, 58. J. N. Rodríguez de San Miguel, Manual de providencias económico-politicas para uso de los habitantes del Distrito Federal, 215 .

${ }^{\circ}$ Cf. Alamán, Op. cit., I. 57. and Altamira, Op. cit., III. 314. 
The method of choice of the city officers was subject to notable variation. In new conquests it was usually the privilege of the leader of the expedition (governor, adelantado, captaingeneral, or whatever was his title), to nominate the first set of officers for the towns erected within the area of his roughly delimited royal grant. This power was conceded by specific permission contained in the conqueror's capitulación or grant, as in the case of Pizarro at Lima (1535), of Pedro de Alvarado at Santiago de los Caballeros (1524), and in numerous other cases. ${ }^{10}$ If this privilege was not specified in the capitulacion, the municipality was organized by means of an election in whch participated every free member of the expedition; nomination by the conqueror was, however, the normal and more usual method. Usually, when the first group so appointed or elected had served a natural year, which was the prescribed term of office, the retiring regidores designated their successors; certain conquerors, Pizarro and Alvarado again as illustrations, named the successors. Until 1621 or 1622 the oficiales reales or treasury officials, whose principal duty it was to care for the interests of the king's revenues, sat in the municipal cabildos "with voice and vote." Restrictions on this practice had begun in 1567, when the oficiales reales were forbidden to serve as alcaldes.

The periodical renovation of the city's governing body was attained not only by the annual election, but also by the provision that no regidor might be re-elected until one year had elapsed since his term of service; in the case of the alcaldes ordinarios at least two years must have so elapsed. The efficiency of this inhibition was largely nullified in practice by the rotation in office of members of a few allied families, who maintained oligarchical control in alternation.

It was the royal intention, as evinced in the earlier legislation, to prevent the central authority, represented by the viceroys and governors, from intervening in municipal elections, but the laws to this effect were nullified in practice by the central officers, who had the legally prescribed power to confirm or disapprove the annual elections. An instance of such interference occurred in Buenos Aires in 1590, despite the efforts of the cabildo to prevent. Again in 1609 Governor Saavedra of Buenos Aires named an alguacil (marshal) "with voice and vote" in the cabildo.

"In the towns which sprang up about the presidios, the municipal cabildo might remain absent for a long perfod, as in the case of San Francisco, California, which exfsted from 1776 to 1834, without the cabildo organization, Moses, $O p$. cit., 17-18. 
The perpetual regidores (of whom more later) acceded to the illegal appointment, but the elective regidores resisted until the governor coerced them by a fine of five hundred pesos each. Not only fines, but imprisonment, resorted to repeatedly by governors, served to enforce their predominance, which brooked no opposition. So far was the practice carried that men refused to accept municipal office, like the senators of the Roman Spanish towns, until fines were imposed to oblige them to accept.

Not only was the elective faculty overridden to a large extent by the viceroys and governors; still another feature of administration served to reduce it. This was the practice of selling offices, due to the impecunious condition of the Spanish crown. The Catholic Kings had forbidden the sale of offices, and Juana la Loca had restricted it to non-judicial of fices; by the end of the seventeenth century, however, the practice had become settled and general. Frequently public offices were disposed of by auction to the highest bidder. In Buenos Aires in 1644 a number of regidorships were auctioned, bringing revenues from eight hundred and fifty to twelve hundred and fifty pesos. The position of alcalde de la Hermandad, thus disposed of in 1671, produced thirteen hundred pesos. Lesser municipal offices, as those of escribano (notary) and alguacil mayor, were leased or farmed for a lump sum to be covered by the incumbent from fees collected. ${ }^{11}$

Navarro y Lamarca, following several writers of the epoch during which the practice of selling offices was in vogue, thinks that the system has been overcriticised, and that the men who bought offices were more inclined to administer them conscientiously than were the "irresponsible and voracious minions of the viceroys." The same author calls to attention the fact that Montesquieu considered the practice advantageous and perfectly proper. ${ }^{12}$ Insofar as his efficiency was concerned, it may be safely asserted that whether the position of the regidor was obtained by purchase or by election, that accident was of less importance in determining his value to the State than was the fact that the whole political heirarchy of the Spanish empire, colonial and peninsular alike, was characterized by malfeasance and graft. with such notable exceptions that honesty in office was the crowning virtue whereby many names of colonial administration have become conspicuous if not illustrious.

"Sarcia, La ciudad indiana, 170-171.

12Op. cit., II, 341, note 1, citing L'Esprit de lois, Cap. XIX, Cf. E. B. Bourne, Spain in America, 227-229. 
One very notable effect of the sale of offices was the tendency of the central authority to increase unduly the number of them for the sake of the revenue thus produced, regardless of the consequence to efficiency. This caused a cynical attitude toward tenure of office which did not a little to destroy the public spirit of the colonists. The customary sale of the office of regidor seems at no time to have eliminated completely the feature of election of at least part of the municipal corporation. Six of the regidores of the City of Mexico were elected every two years by the perpetual regidores, who held by purchase or inheritance; this at the close of the eighteenth century. ${ }^{13}$ The power to appoint perpetuos had, indeed, been held by some of the earliest conquerors; Pizarro, by the terms of his capitulacion, could name three of them. The purchase of the regiduria perpetua by well-to-do families gave in time to the creole families of colonial society their one avenue of admission into participation in la cosa pública, though it is true that at times, through default of suitable Spaniards, the creoles came into control of the audiencias (supreme courts of justice with certain administrative functions). It may be little doubted that the preponderance of the creole element in the cabildos was one of the compelling motives for the policy pursued by the Spanish government in emasculating these as authoritative bodies.

So much, briefly, for organization and perpetuation of the cabildo. Of equal interest is the subject of the general powers of the municipal corporation. These were both administrative and judicial for their areas, but their range was limited by the original grant of privileges, and more especially as time elapsed, by the issue of ordinances for municipal guidance by the viceroys and audiencias. The general laws of the Recopilacion de Indias combined with these ordinances to reduce the initiative of the city government to a minimum. Judicial functions were supposed to be exercised by the alcaldes ordinarios in first instance in both civil and criminal suits. In civil suits involving certain sums the cabildo was a court of appeal also from the decisions of the alcaldes: it might itself be appealed to from the governor, though the practice of the audiencias of sending out special judges for causes of consequence gradually limited the bases for appeals which would normally have gone through the municipal courts. ${ }^{14}$.

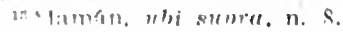

whibilte Villaroel. Enfremederles politicas gue padcee esta capital de Nucva

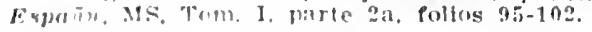


In affairs of administration the cabildo was theoretically independent in everything that had to do with the adornment of the city, the improvement of its public works, regulation of economic affairs, such as fixing the prices of products, wages, and the levy of local taxes, the inspection of jails and hospitals, administration of the public lands (of which more anon), and the oversight of public morals. All of these cares of the municipality were by a cédula of 1535 carefully distinguished as administrative and not judicial; so as to forestall the intervention of the judges of the audiencias in them: As a matter of fact, however, the cabildos were in all of the above matters under the domination of the $c 0-$ riregidores or governors, who presided over them and had the power of executing the acuerdos (votes) of the capitulares, and these decisions they often modified or nullified through interpretation or neglect. The corregidores were notorious for their injustice in the division of the public lands and in their efforts to profit personally from the exercise of authority:

The cabildo deliberated usually in secret, that is, there were not public hearings of their sessions, and the capitulares were bound by oath to maintain secrecy in regard to their deliberations. Notable variation from this procedure occurred when, for the purpose of negotiating a forced loan (donativo), for the king, the influential and well-to-do members of the community were invite $d$ to join what was known as the "cabildo abierto" (open town meeting). Such meetings occurred frequently in Buenos. Aires during the seventeenth century. ${ }^{15}$

A still more noteworthy development of cabildo government occurred in the earlier part of the Spanish domination. In the island of La Española there began, shortly after the initiative of the settlers had brought about the establishment of municipal governments, the practice of holding assemblies of the procuracores of the towns after the manner of the gatherings of the Cortes in Spain. These convocations had the right of assembling without the call of the governors, and were empowered to authorize the latter to execute whatever might be conducive to the general welfare. This created a type of resolution which was used as a temporary substitute for the decision of the Council of the Indies, which, arriving tardily, as was frequently the case, was often found inapplicable to the situation which it was intended to affect. The assembly of the procuradores also came into

${ }^{15}$ Garcia, Op. cit.. 199-201; cf. Bernard Moses, "The Colonial City," Chap. XVIII. Vo.. II, of his 'The Spanish Dependencies in South America. 
vogue in Cuba; it met annually at Santiago de Cuba for the purpose of recommending to the king measures of state interest and reporting to him the necessities of the island, together with petitions that he supply them. This practice was in vogue as late as 1532 and 1540, as records of such assemblages bear these dates. On the continent the practice was continued, particularly in New Spain and New Castile, where the congresses of the towns were recognized by Charles $V$ in cédulas which gave to Mexico and to Cuzco, respectively, the right to the first vote in the assemblies. During the sixteenth and seventeenth centuries no less than forty such assemblies were held, though little is now known as to their history and effectiveness, save that they were, of course, means of communication and retition. ${ }^{16}$ The congresses of New Spain, says Alamán, writing of the beginning of the independence period, had long ceased to meet.

Of a congress of the towns of New Spain which met in the year 1528 , it is recorded that the purpose of the convocation was to send a representative to court with suitable instrustions. Procuradores of the towns of Mexico, Vera Cruz, Espíritu Santo, Colima, and San Luis participated in the deliberations "in order to discuss and vote upon what might be to the service of God and his Majesty anci to the rerpetuity of this land." At this session, May 26, two procuradores were elected to be sent to Spain. On June 1, another session voted to give these agents a salary of four ducats per diem from the time they should leave Mexico City until they should have fulfilled their mission. The towns prorated among themselves a fund of nearly seventeen hundred pesos for this journey in the following proportions: Mexico paid eight hundred pesos, Vera Cruz three hundred, Espíritu Santo seventy, Colima fifty, Zacatula two hundred and fifty, San Alfonso de los Zapotecas fifty, San Luis one hiundred. In 1528, when Dr. Ojeda was making a voyage to Spain, the congress had voted him a commission "to negotiate with his Majesty. to have granted to the city of Mexico, in the name of this New Spain, a voice and vote in the Cortes which his Majesty and the kings his successors might order convened." This privilege was granted. ${ }^{17}$

${ }^{13}$ Altamira, $O p$. rit., III, 316, cf. Alaman, Op. eit.. I, 39, 58.

${ }^{7}$ Alamán, Disertactones sobré la história de la Remblića Mexichina! II, $315-316$ : cf. Id. I 167. 259. Stee also Copra de la mayos marte y mus importante y itil del

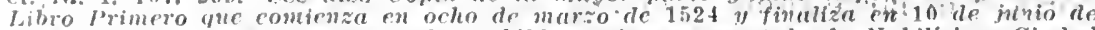
1529 en que sc asenlaron tortos los cubildos y juntas que tubo la Nobilisina Ciudad de verico on dicho tiemeno. MS. Follo 237 . Tater interesting material on the municipal legine of Mextco is contained in the Traluccisn naleografica del libro cuarto de calilde de in Cimalad de Meriro. Mexico. 1874. This imnrit covers the period from Jinnuary 1, 1536. to August 20, 1543. The printed Actas del Cabildo del anumamicuto corstitutiounl de Mexiro. (Moxico, 1S59-1905) cover the years 1524 to 1619, and 1883 to $18: 4 \%$ 
One of the most important of the matters which concerned municipal existence in the Spanish colonies was the disposal and utilization of the land. Whether a town were founded by a conqueror or by: a group of voluntary associates, the crown theoretically conceded to the new venture a grant of land four leagues square. The actual amount of land was, of course, modified by situation and other physical accidents. The basis of the subdivision (repartimiento) of the land was to provide suitable grazing and arable areas. In conformity with the usual European custom, land for residence purposes was distinct from that used for other purposes. First, then, were set aside at the center of the settlement a sufficient number of town lots (solares), around which was a strip of commons (ejidos) for various communal uses; beyond these were the dehesas y tierras de pasto, or grazing grounds, and the municipal grounds (propios) for lease for revenue under a system of perpetual leasehold payment, known as the censo. Aside from these lands, there was apportioned onefourth of the remainder to the principal conqueror, and the remainder to the other settlers by peonias and caballerias, that is, in portions for footsoldiers and horsemen, varying. in number granted to each in ratio of their importance or merits. It would be beside the present subjest to go into the matter of the disposal of all these lands, and it is sufficient to say that it was from the propios that the municipality exrected, when it had them, to derive a large part of its revenue. Accretions of numbers of new citizens, such as occurred at Buenos Aires after the original allotments, invaded the areas set aside as propios and impoverished the towns in proportion. Often, too, there were no lands actually set aside and utilized as propios, so that municipalities frequently lacked entirely this source of revenue. Other income was provided from the arbitrios, which were duties collected by the towns from mercantile business, trades, and products. From all sources the sums obtained were comparatively meager, and the control of the cabildo over them was limited as we shall see.

The establishment of a city of importance was sometimes accompanied by, but more frequently followed by, the granting of honors and distinctions attended by pomp, circumstance, and formality. These were not uncommonly conceded for the payment or gint of large sums of money needed by the monarch. The city was for some such consideration granted use of an heraldic device, the symbols of which commemorated noteworthy features of the 
locality, an incident of the conquest, or the union of the city with the crown of Castile. ${ }^{1 s}$

The title of Muy noble y leal was usually prefixed to the designation of the city, and these words were used in correspondence or official documents. The City of Mexico was by order of Charles V, on July 24, 1548, designated "La muy noble, insigne, $y$ muy leal e initperial ciudad de Mexico," which "shall enjoy the privileges and preëminences of grandee, as metropolis of this New Spain." In the official correspondence a city of this rank was addressed as "Ilustrísimo Señor."

Pomp and ceremony were observed, with careful regulation of the proper precedence of the municipal officers, when the corporation sallied forth "en cabildo" from the casa de ayuntamiento upon festival occasions, such as the celebration of the town's Saint's Day, to meet and greet a new viceroy, governor, corregidor, or what not. The installation of the corregidor of Mexico, 'as prescribed by the ordinance of 1728 , affords a good illustration of municipal formality. ${ }^{13}$ The corregidor, after his election by the king, was required to notify the cabildo of his coming. That body went out in array to meet him and conducted him to the viceroy, of whom he was required to ask permission to present his title to the audiencia. This arranged for, the cabildo and retiring corregidor conducted the new appointee to the town hall, where he was to take up his residence. After the ceremony of acknowledgement of his title by the-audiencia, a day for his formal reception by the cabildo was set by the neiv'corregidor. At this quaint ceremony the retiring corregidor and the regidores rose to their feet with bared heads as the new corregidor entered their presence. The retiring exezutive rezeived into his hands the royal appointment of his successor, kissed it, and placed it upon his head in token of obedience; he was imitate l in this formality by the ranking regidor, the other capitulares remaining standing the while. This done, the new corregidor was required to take an oath to perform his office well and faithfully, to defend the purity of the Immaculate Conception of the Blessed Virgin, and to preserve the fueros and preëminences of the city, to keep secret the business conducted in cabildo, and to strive in all things to keep the republic in reace, doing all that he could to promote the happiness of the king's vassals: 'He was thereupon

1hAntonio Peñaflel reproduces many of these heraldic devices in his Ciudades coloniales "capitales de la Republica Mexicuna, s vols., Mexico, $1908-14$.

${ }^{16}$ Rodrlguez de San Migues. Munual de providencius, pages 187-247. 
presented with the staff of office, which was the public symbol of his rank and importance. Invested therewith, he stepped to the right hand of his predecessor, whom he thanked and congratulated. The record of the ceremony was required to be kept in the minutes of the Libro de Cabildo, which today furnishes so much interesting and valuable history of colonial municipal life. ${ }^{20}$

In the first meeting of the cabildo after his finstallation, the new' corregidor was notified that he must, within thirty days, post bonds for the residencia (judicial inquiry concerning administrative acts) which legally attended retirement from office in the Indies; if he failed to do so he was to forfeit his salary for the period of his delay. After all this had been done, the new corregidor escorted his predecessor to his new private residence, and then, all formalities having been complied with, a full and circumstantial report of his induction into office was sent to the viceroy and to the Council of the Indies.

How insistent the cabildos were upon their privileges and preëminences is shown from an occurrence wherein the cabildo of Guatemala came into conflict with the royal audiencia residing in the same capital upon the occasion of the reception of a newly appointed bishop of that see. In 1737 the cabildo complained that it had been prevented from seating its two alcaldes in the choir of the cathedral in the seats of the dean and the archdeacon during the installation of the bishop. This ancient "fuero y privilegio" was denied the secular cabildo by the religious cabildo (chapter of the cathedral). The president of the audiencia was appealed to, but he gave no comfort to the insulted alcaldes, refusing to intervene for them, but on the contrary ordered the secular cabildo to attend the ceremony in a body. When they refused, he designated them "inobedientes," fined them five hundred pesos, imprisoned them, and deprived them of their arms and insignia. The audiencia named new alcaldes. and regidores, with whose attendance the installation of the bishop was.celebrated. The crown absolved the capitulares of their fines and

${ }^{20}$ Among, the municipal documents avallable in print, besides those for Mexico City mentioned above in Note 17, are two small volumes for Guatemala, edited by Rafael Arévola: Colección de documentos antigïios del archivo del aynntamiento de la Ciuclad de Guatemala. Guatemala. 1S57; and Libro de aetas del ammtamiento de la Ciudad de Santiago de Guatemala. Comprende los seis primeros años dęsde In fundacín de la misma chulad en 1524 luasta 1530.... Guatemala, 1856. For Buenos Aires there have been published the Acuerdos del extinguido cabildo de Buenos Aires. $1907-08$, and the Docunentos "planos relativos al periodo edilicio colonial do la Cindad de Buenos Aires, 5 v., Buenos Aires, 1910. The municipal life of Santiago de Chile is recorded, with documents, in $\mathrm{M}_{.}$. L. Amunategui, El Cabildo de Santiago, desde 1573 hasta $1581 \ldots \ldots 3$ volumes, Santlago, 1890-91. 
restored them to their positions and honors, but the characterization of "inobedientes" was left standing. To overcome this, the capitulares appealed to the crown to order the audiencia henceforth to observe its legal limitations and not interfere with the regulations prescribed for ceremonies in which cabildo and audiencia were to participate. In November of 1737, the king answered this petition by ordering the president of the audiencia to hear both the audiencia and the cabildo and report his findings to the Council of the Indies. His report the following year showed that the audiencia had arrested the cabildo "first, to maintain its own decorum and authority, and, second, because the plebeians were watching to see what would happen between the audiencia and the cabildo." But, as the capitulares had shown that their refusal to attend the installation was not due to a spirit of disobedience, but merely to preserve their privileged preference in the matter of seats, the president judged that they were without real blame.

To cut the story short, the king in 1740 ordered that the audiencia should henceforth refrain from attending episcopal installations in a body, and that the alcaldes ordinarios be restored to the ancient seating procedure which obtained before the $a u$ diencia began (illegally) to participate in this ceremony. ${ }^{21}$ The incident illustrates the length to which municipal bodies were willing to go to maintain their "ancient privileges," and shows how puerile some of these were. It also points illuminatingly to some of the difficulties with which the Spanish crown had to contend in administering its colonies. The quarrel had lasted three years, and numerous hearings had been held both in Guatemala and Madrid before the childish difference was settled. Interest attaches also to the fact that in this instance the cabildo was victorious over the audiencia; rather the exception than the rule.

During the rule of the House of Hapsburg the political institutions of the Spanish empire suffered from the gradual decay which brought threat of disintegration at the time of the demise of the last monarch of that line, Charles II. When the House of Bourbon ascended the throne in the person of Philip V, the policy of the nation became one of general reform, based on the French model of administration. So far as the Indies were concerned there were not marked symptoms of this change until the time of

2!R. Arévalo, comb., Colccrion de documentos antigïos del archivo del ayuntaniento de la cludad de Guatemala, 9-13. 
Charles III (1759-1788). That benevolent despot began his program of rehabilitation by sending to New Spain the distinguished visitor-general, José de Gálvez. This minister was instructed, among other things, to take note of the condition of the municipalities, particularly for the purpose of reforming their financial systems so as to prevent malversation of funds, the conspicuous sin of municipal administration. In 1767 he began this work while on a visit to the northern provinces of the viceroyalty. The cities of San Luis Potosí and Guadalajara were found to have allowed their cabildos to fall into desuetude, a condition widespread in Spanish America at that time. In San Luis Potosí there were only two regidores, and these mere lieutenants and not proprietarios as they should have been; one of them was also alcalde ordinario, which he should not have been. Gálvez accordingly caused six new regidores to be elected for a term of one year, the number thus being made eight. The city was also now divided into ten barrios, or wards, each of which was placed under control of a regidor or an alcalde. A list of all the resident tributaries was ordered made, and the neglected practice of guarding the municipal treasure by use of the strong box with three keys was restored according to law. Similar provisions for the revivification of Guanajuato were made by the visitor-general at this time.

Upon his return to the capital, Gálvez found that an investigation of the cities of the viceroyalty which he had inaugurated had disclosed unbelievable disorder and confusion in municipal finance. In many towns no account books had been kept at all, even for the simplest receipts and expenditures. 'The situation was so bad that it was thought wise to establish in Mexico City a contaduria general which should keep the accounts of all the municipalities. After the establishment of this accounting office no expenditures of city funds might be made by regidores without prior consent of the contador general. Plainly this reduced the municipalities to a level of irresponsibility which was later to be surpassed by the provisions of the Ordinance of the Intendants, which went into partial effect in $\mathbf{1 7 8 6 .}$

For the City of Mexico the reforms of Gálvez were embodied in an ordinance promulgated by the viceroy in 1771 . The essential feature of this ordinance was the increase of responsibility placed upon the municipal officers with decrease of salaries and fees. Duties such as the inspection of markets, of weights and measures and other cares grouped under the heading of policía (good gov- 
ernment) were still, as under the old regulations, to be performed by committees of the regidores in annual turn, but without the extra pay which had previously been conceded. The independence of the corporation was, by the minute provisions of the ordinance, reduced to the vanishing point.

Interference of the viceroy with the municipal body was emphasized by another ordinance emanating from the visitor and the viceroy for minute regulation of the bakers' guild of the capital. There were at that time, or shortly after, some fifty guilds of trades workers in the city, management of which gave to the government much concern. These might well have been cared for by the cabildo; but when the viceroy of a great kingdom like New Spain, twice as large as modern Mexico, could descend to the details of regulating the number of bakeshops and the size and price of loaves while the fieles executores (judges of weights and measures) of the cabildo sat by in silence waiting the issue of his dispensation, there couid have been little left to the discretion or self-respect of the cabildo.

The Gálvez reforms contained still another manifestation of the centralizing policy of Charles III. This was the appointment by the viceroy of six regidores honorarios to sit with the twelve (later fifteen) elected and hereditary capitulares, without salary and in a purely advisory capacity. This was in emulation of the new system then in force in Madrid. The purpose was, of course, to give the viceroy closer oversight of municipal affairs and enable him better to oppose the radical creole element by drawing his appointees from the more conservative Spanish group. The regular members of the cabildo were restive under the new arrangement, and in 1794 obtained the power to nominate the honorarios; this continued until independence, and of course, did away with the effectiveness intended by their institution. ${ }^{22}$

The municipal reforms initiated by Gálvez during the visitation of New Spain were incorporated in the legislation establishing the intendancies which went into partial effect in New Spain in 1786, similar legislation having previously been applied

\footnotetext{
=Reglamento a instruccion alcl visitador gencral Don José de Gálves para la Nobilisima Ciudad de Mŕriro. mandada obsrrvar por el Marqués de Crois en decreto de 22 le Enero del año de 1771 (Mexico, 1771), passim.

lieglamento del gremio de penaderos ir esta capital vara su abasto y ereción de un prisito ale trigos y harinas a beneficio de su comin (Mexico, 1771), passim.

Revilla Gigedo, Juan Vicente. Instucrion reservada que el Conde de Revilla figedo dió a su suresor en el mando, Marquís de Branciforte, sobre ch gobicrno de este rontinrnte rn al tirmmo rn ane fur su vire" 1.Mexico. 1831), Articles 154-156.

Priestley. II. I. José de Gálvez, Pisitor-gencral " Ne1o Spain, 1765-17i1. 22226. $296-303$,
} 
in some measure in Havana in 1764 and in New Spain itself by Gálvez in 1765 (he being an intendente de ejército himself), and in Peru in 1782. The viceroy Revilla Gigedo was obliged to confess in 1794, however, that the provisions of the Ordenanza concerning municipal regulation had not yet been enforced. ${ }^{23}$ Under its provisions, the intendentes (who superseded the governors and corregidores) were supposed to frame regulations for the control of town revenues derived from lands and buildings, that is, the propios. These regulations they were to submit to the Junta Superior de Real Hacienda (the standing administrative committee of the treasury system) for approval, but they had neglected, said the viceroy, to do either. As a result, there was no improvement in the chronic malady of the municipalities. "Malversation of public funds is a common and inveterate evil....concerning which José de Gálvez.... later marqués de Sonora, labored most and gathered least fruit." ${ }^{4}$

But the life of the municipality was depressed in other ways than those which affected finance. Under the Ordenanza de Intendentes the local autonomy was completely prostrated by the absorptive action of the Junta Superior de Real Hacienda, the viceroy, and the "intendant-governors." Francisco de Croix in Mexico exercised his viceregal talents in supervising the cleaning of the streets, (at a later day Revilla Gigedo was fain to order the dung-hills out of the thoroughfares) repairing roads, providing pure water, public baths, illumination, hospitals, jails, foundling homes, and so on. All were, of course, necessary and valuable improvements, bringing the vassals willy-nilly into contact with the amenities of civilization, but the tragedy lay in the spirit of the system which brought the viceroy, the alter nos of royalty, drawing a salary of eighty thousand pesos per annum, to performing tasks which lesser men could have done as well if educated to responsibility and given normal outlet for self-expression in activities which form beneficent safety-valves to large groups of citizens who in flourishing democracies find fields thus opened to them for useful public service.

The Ordenanza gave the cabildo, so far as it was the means of conserving the self-respect of the towns, the coup de grace. Its nullity, long existent, was now given the sanction of law, the capitulares being given the merely routine drudgery imposed by central authority.

${ }^{2}$ Revilla Gigedo. Instrucción reservada, ubi supra: Real ordenanza para el establecimiento $e$ instrucción de intendentes (Madrid, 1786). Articles 2S-5.3.

${ }^{24}$ Revilla Gigedo, Instrucción reservada, ubi supra. 
The intendant of the province presided over the cabildo (as had the governor, theoretically, before him), kept the accounts of the propios; and reported the condition of finances to the Junta Superior, or else as in Mexico, neglected to do this at all. He divided the town funds into groups, that is, budgeted them, as prescribed by the Ordenanza, being guided in his expenditures by the hard and fast provisions of the general law. To complete the control, the regidores were practically eliminated from intervention in fiscal matters by the appointment of municipal juntas composed of the alcalde ordinario, two regidores, and the procurador. These committees had authority to manage city funds without the intervention of the other capitulares. The intendant also took over the supervision of agriculture, commerce, mining, forests, roads, streets, inns, public parks, and municipal buildings. $\mathrm{He}$ or his asesor (adviser) took over the guidance of municipal justice. In this duty the asesor letrado preserved the tradition of bulldozing the regidores with the same tyrannical cynicism that had been the chief characteristic of the deposed corregidor. The Ordenanza prescribed the intervention of the intendant or his asesor in matters of justice "to prevent the municipal judges from acting with partiality, passion, or vengeance." ${ }_{25}$ But the asesor took it upon himself to intrude in all the deliberations of the cabildo; indeed, his manner of doing so was not, as instanced at Santiago de Chile, calculated to retard the inevitable process which eventuated in independence. "The asesor letrado," it was reported to the king, "does not treat the cabildo with that respect and moderation imposed by law and ceremonial. He interrupts with insulting words the most serious functions of this respectable congress. To make detailed statement of the outrages which have been endured by the members of this venerable corporation of the republic would be to descend to petty prolixity or to confess excessive affection for distinctions; hence, let it suffice to say that ever since the asesor assumed his duties there has been none of that peace which was enjoyed in earlier but less quiet times, because he believes that he can make his opinion prevail in the sessions of the ayuntamiento against the opinions of all the rest, by interrupting and depreciating in harsh and insulting phrases the opinions which he considers opposed to his own." ${ }^{26}$

2Real ordenanza, article 28: Garcí, La ciudad indiana, 293.

${ }^{2} \mathrm{Ga}$ cia. I. ciudad indiana, p. 294, citing M. T. Amunategul, Los precursores de la independencia de Chile.....3 volumes, Santiago, 1870-1872. 
In résume then, it is apparent that the municipality was brought to the New World with the tradition of the ante-sixteenth century autonomy still alive, but that the expression of that autonomy in America was a mere flicker of the old-time independence extinguished by Charles $\mathrm{V}$ on the field of Villalar. The embryonic Cortes survived for more than a century in America, but only by sufferance of the monarch, and representation of the towns in the Spanish Cortes suffered all the vicissitudes of the peninsular organization plus the inherent difficulties of great distance, stormy seas to cross, and the tradition of colonial subordination to peninsular welfare. While the colonies grew in population, while the cities developed in size and opulence, their juridicial status, which should have kept pace with material success, was consistently sacrificed by a policy which feared the creole and meztizo, which based colonial welfare and imperial integrity on the exclusion of the colonist from participation in la cosa pública because he was, as a result of the completion of the vicious circle, very seriously incapacitated for proper discharge of the duties of citizenship. Small wonder that the cities, thwarted in the normal development by centralist control, became the centers of revolt and separation from Spain. After that, once free from the decrepitude of the declining control of the fatherland, they became centers of separatism and disintegration that defied for nearly a century the development of reasoned and self-directed nationalism.

Herbert Ingram Priestley.

University of California, Berkeley, California. 
' 


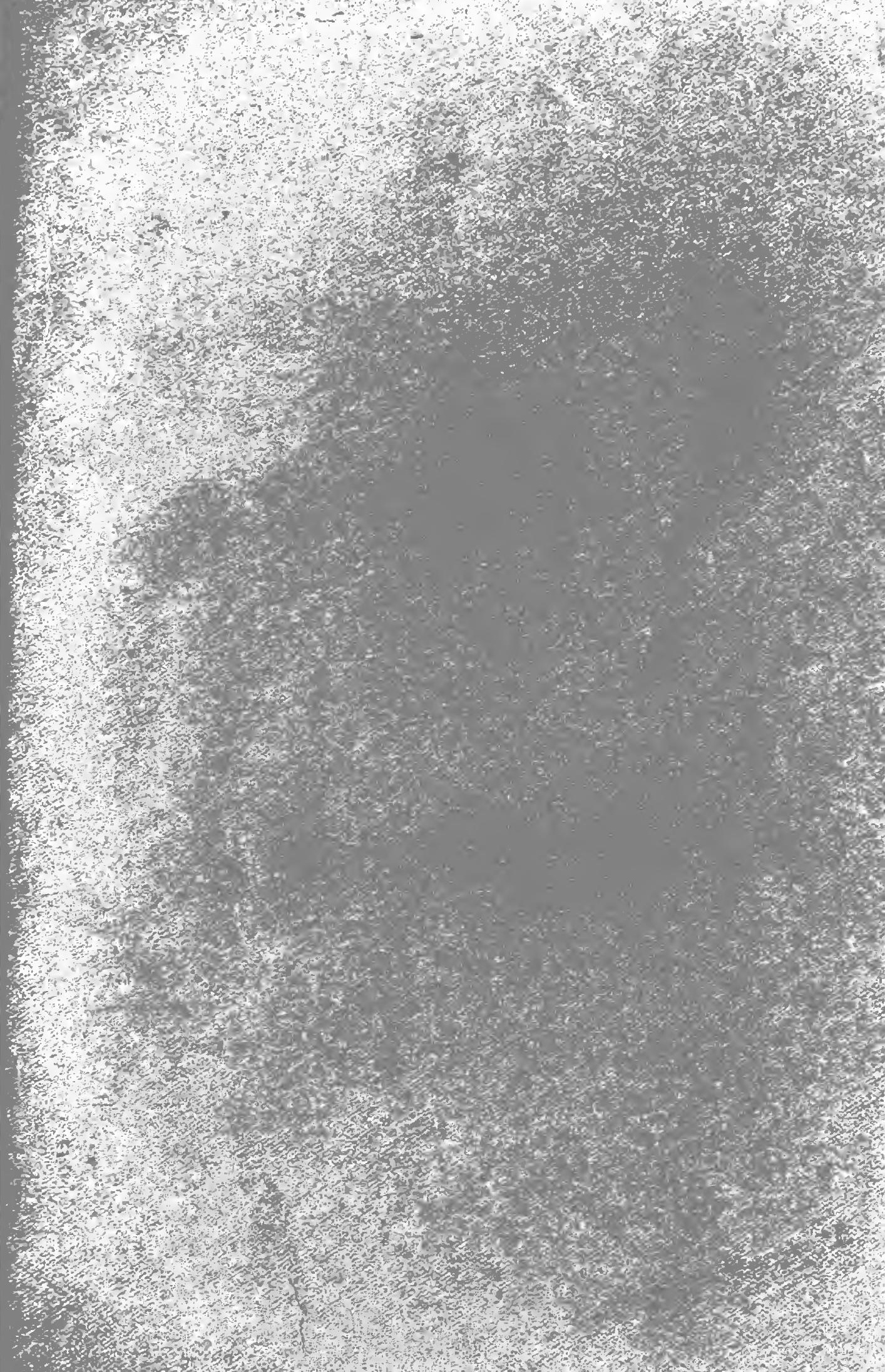




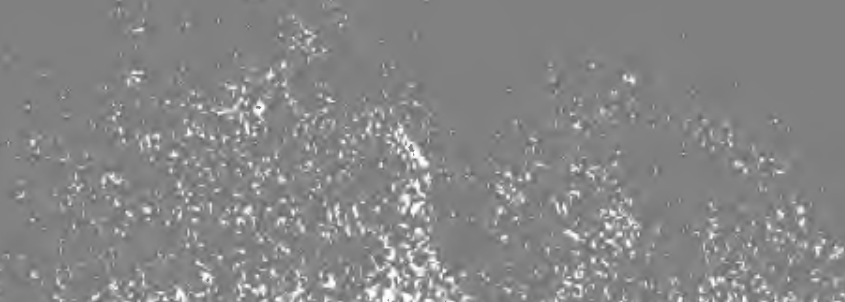

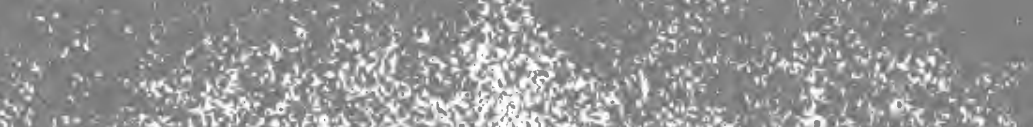

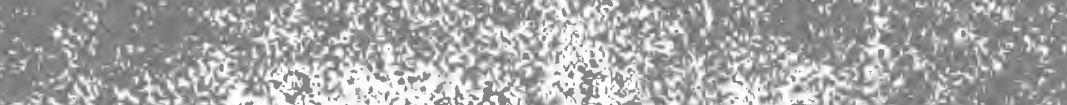
3. if

(x)

5 ton

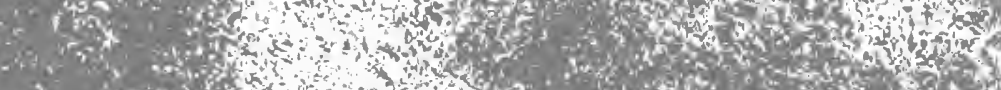

$\therefore$ moth

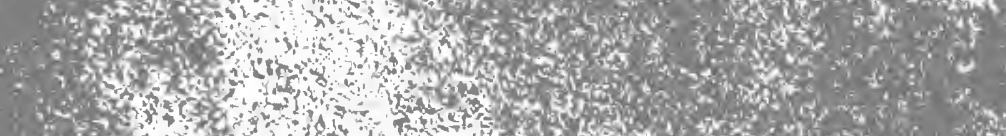

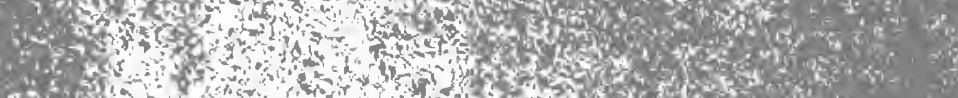
5000

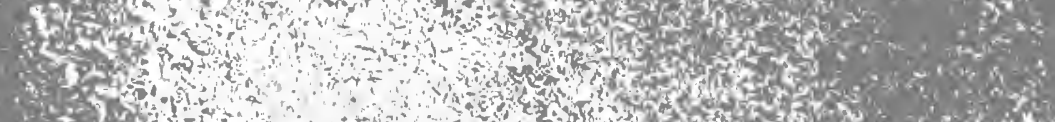

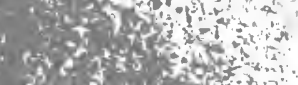

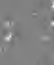




\section{tos

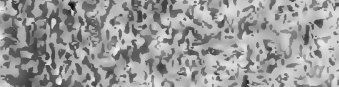




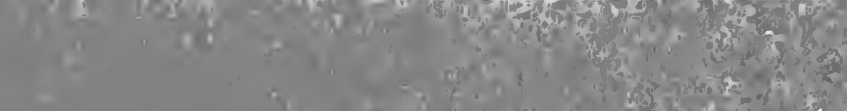

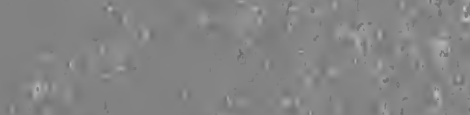

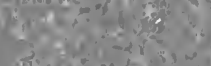

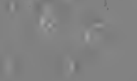

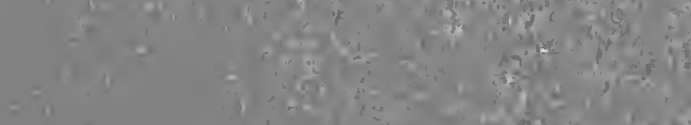

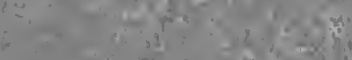

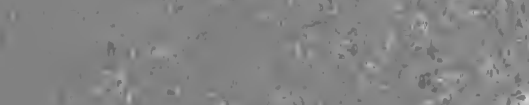

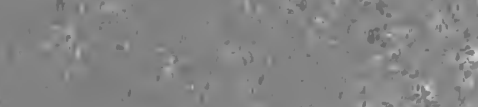

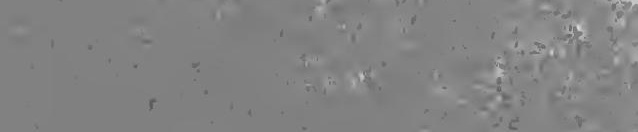

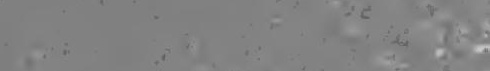

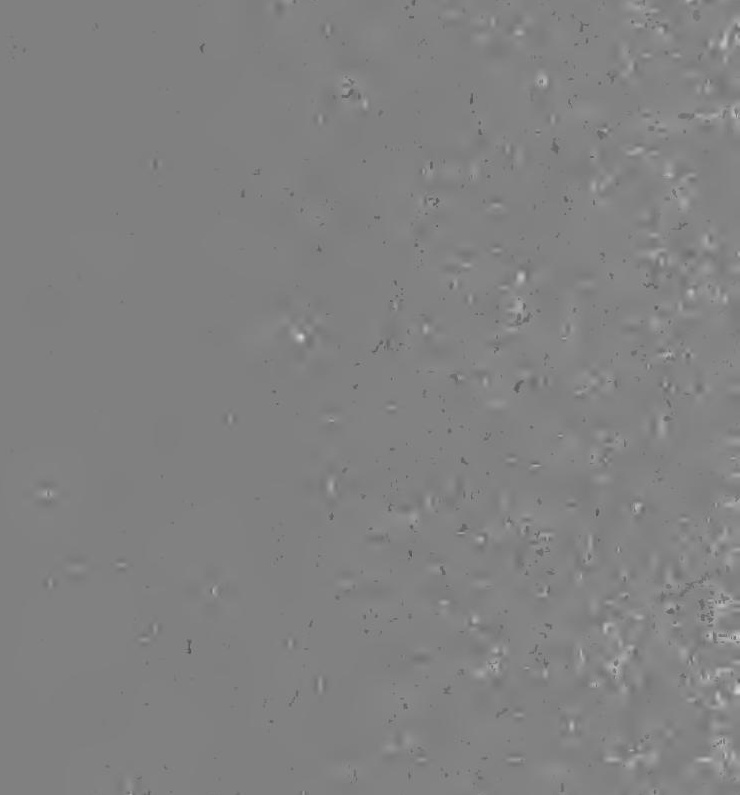

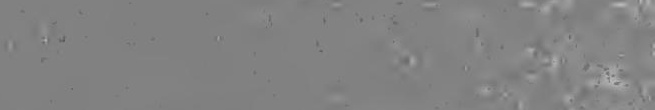

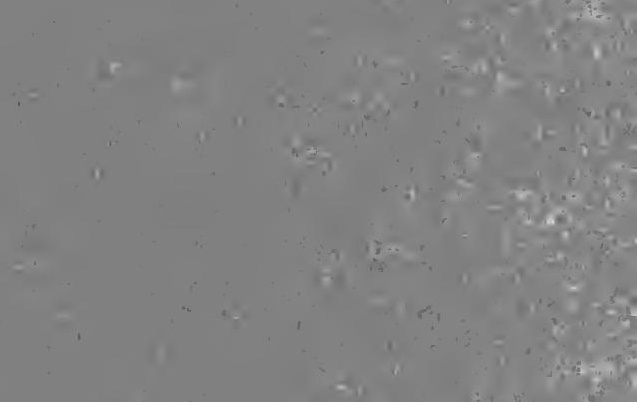

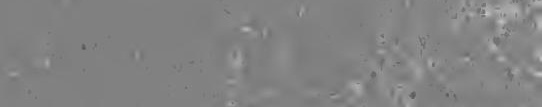

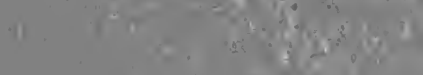

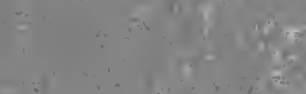

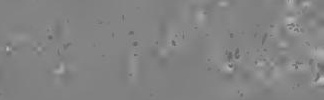

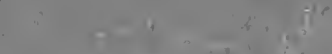

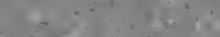


